\title{
PRELIMINARY HEARINGS ON INDICTABLE OFFENSES IN PHILADELPHIA*
}

In recent years, numerous Supreme Court decisions have stressed the necessity for prompt production before a magistrate of arrested persons. ${ }^{1}$ The length of time permitted between arrest and this production ${ }^{2}$ remains, however, a matter of state law. ${ }^{3}$ Prompt production constitutes the major deterrent to so-called third degree methods by the police and recent comment has been primarily concerned with the prevention of these illegal police techniques through stringent enforcement of arraignment requirements. ${ }^{4}$

Generally, arraignment is combined with a preliminary hearing before a committing magistrate to determine whether the accused should be held for the grand jury.5 To hold the accused the prosecution must show probable cause that a crime has been committed and that the accused has committed it. ${ }^{6}$

Presumably one major advantage of combining production of the defendant with this preliminary hearing is that the requirement of an immediate showing of probable cause will deter illegal arrests. The standard for a legal arrest is similar to that for committal and if the initial arrest was proper the accused should generally be held. ${ }^{7}$ However, a substantial number of police arrests are made without reasonable grounds. ${ }^{8}$ Subsequent

* This study was financed by a grant from the Thomas Skelton Harrison Foundation, an agency created by the will of Thomas Skelton Harrison to promote good government in Philadelphia. The editors sincerely appreciate the cooperation of $\mathrm{Mr}$. Jerome Balka of the Philadelphia District Attorney's office, and the assistant district attorneys, policemen, and magistrates who consented to interviews and aided in the finding of much of the necessary information.

1. See Mallory v. United States, 354 U.S. 449 (1957) ; Stroble v. California, 343 U.S. 181, 197 (1952) ; Upshaw v. United States, 335 U.S. 410 (1948); Lyons v. Oklahoma, 322 U.S. 596, 597 (1944) ; McNabb v. United States, 318 U.S. 332 (1943).

2. The term arraignment will be used synonomously with production of the defendant before the magistrate. See Frankfurter, J. in Mallory v. United States, supra note 1 .

3. Ibid. The Supreme Court of Pennsylvania has recently stated that "there is no prescribed time within which a preliminary hearing must be held." Commonwealth v. Shupp, $365 \mathrm{~Pa} .439$, 446, 75 A.2d 587 (1950). However, the District Attorney's office in Philadelphia has promulgated a rule that persons arrested before 8 A.M. are to be brought before the next regular sitting of the magistrates court at 9 A.M. so that no detention can exceed twenty-five hours. Districr Atrorney's OfFice of PhILAdELPHIA, ANNUAL REFORT 10 (1952).

4. Putrkamimer, Administration of Crmminal Law 72 (1953); Reppy, Civil Righis IN THE UNITED STATES 230 (1951).

5. Carringer, Procedure Before Commitring Magistrates in Peinnsylvania 80 (1947).

6. McNair's Petition, 324 Pa. 48, 187 At1. 498 (1936). Orfield, Criminal Procedure From ARrest to Appear 49 (1947).

7. Note, Philadelphia Police Practice and the Law of Arrest, 100 U. PA. L. Rev. 1182,1185 (1952).

8. Ibid. 
questioning of the suspect and investigation while he is in custody may then reveal that there is probable cause for holding him. A prompt preliminary hearing should eliminate excessive police reliance on such post-arrest investigation.

Thus, a major purpose of the preliminary hearing is protection of the individual's right against unlawful arrest and detention. Correspondingly, the burden put upon the police by such a system is great. In contrast, most continental countries view the preliminary hearing as inquisitorial in nature and intended to obtain evidence of guilt by interrogation of the defendant. ${ }^{9}$ This paper, the result of a field study of the preliminary hearing in Philadelphia, will consider, in the context of conflicting police and individual interests, the manner in which the preliminary hearing is conducted in that city.

\section{Functions of the Preliminary Hearing}

Traditionally, the major function of the preliminary hearing is the determination of whether there is probable cause to hold the accused. Many prosecuting attorneys feel that at the preliminary hearing the state need only offer proof of a prima facie case against the accused. ${ }^{10}$ On this assumption it is sometimes said that it is not within the province of the committing magistrate to pass on the credibility of witnesses; the accused must be held for the grand jury if one witness swears directly to each element of the offense. ${ }^{11}$ More commonly, however, the magistrate is conceived of as having broad discretion to determine whether probable cause has been shown. Although there is no explicit statutory test for committal in Pennsylvania, the Pennsylvania Supreme Court has stated that the magistrate must exercise his discretion and judgment and that "so long as he renders judgment in good faith, he is accountable to no one." 12

If the preliminary hearing is to serve properly this exculpatory function, the accused should have the right to be heard. In Pennsylvania this right is provided by statute in all cases where the accused so demands except murder, manslaughter, arson, rape, mayhem, sodomy, buggery, robbery or burglary. ${ }^{13}$ Failure to provide for a right to be heard in cases involving the enumerated offenses would appear to be inconsistent with the exculpatory nature of the preliminary hearing and suggests the need for legislative correction. However, in practice, statutory distinctions are

9. Moley, Our Criminal Courrs 36 (1930).

10. Murphy, Proceedings in a Magistrate's Court Under the Laws of New York, 24 Fordham L. REv. 53, 59 (1955).

11. CARringer, op. cit. supra note 5 , at 92.

12. McNair's Petition, 324 Pa. 48, 54, 187 Atl. 498, 502 (1936).

13. Pa. Stat. AnN. tit. 42, §1080 (Purdon 1930). "Hereafter, upon a preliminary hearing before a magistrate for the purpose of determining whether a person charged with any crime or misdemeanor against the laws, except murder, manslaughter, arson, rape, mayhem, sodomy, buggery, robbery, or burglary, ought to be committed for trial, the person accused, and all persons on behalf of the person accused, shall be heard if the person accused shall so demand." 
rarely drawn between those cases in which the defendant has a right to be heard and those in which it is discretionary with the magistrate to allow him to speak. Often the "hearing" involves nothing more than a recital of the accused's conduct by the arresting officer or other prosecuting witnesses. The defendant speaks or not as the magistrate is so inclined. If the defendant is represented by counsel, it is more likely that he will be permitted to present a defense. ${ }^{14}$ But in eighty-five per cent of the hearings the accused is not represented by counsel.15

Even if advised that he has a right to speak, the unrepresented defendant often chooses to remain silent for fear of self-incrimination. The manner in which the assistant district attorneys inform unrepresented defendants of their constitational rights to remain silent seems to imply that it is always to the accused's great advantage to refuse to speak. ${ }^{16}$ of course, the unrepresented defendant should be made aware of the danger of self-incrimination, and in many cases it is difficult to so notify him without frightening him into remaining silent. However, if the magistrate is to properly exercise his function of determining whether probable cause has been shown, the assistant district attorney is under an obligation to carefully explain to the accused the precise effect of his refusal or willingness to testify. This is especially important since the assistant district attorney is himself almost always hearing the case for the first time ${ }^{\mathbf{1 7}}$ and might be inclined to recommend discharge to the magistrate were the case more fully presented.

Another major function of the preliminary hearing is to inform the accused of the offense with which he is charged. In practice, however, the unrepresented defendant will probably not be made aware of the exact statutory offense he allegedly has committed. ${ }^{18}$ The arresting officer will

14. Even when the accused is represented by counsel, some magistrates and assistant district attorneys object to statements by the accused on the ground that the magistrate may not pass on the credibility of witnesses. This position holds that a case is made out and the accused must be held when one witness swears directly to the offense.

15. Foote, Compelling Appearance in Contr: Administration of Bail in Philadelplia, 102 U. PA. L. REv. 1031, 1037 (1954). Out of the 857 hearings, the author of that Article reported defendants to have been represented in only 130 .

16. Their reason for so doing would seem to be not to prevent the accused from defending himself but to expedite the hearings. Apparently, they sincerely believe that once a prima facie case has been made out, the defendant should be held for the grand jury and any other discussion is both time-consuming and dangerous for the defendant.

17. Very rarely does the assistant district attorney know anything more about the case than what appears on his copy of the docket and his "crimmy" sheet which includes the defendant's police record and the official report of the arresting officer. In the central police court, however, specialized assistant district attorneys who have worked with the police investigatory squads will often present the case at the preliminary hearing. Hearings at the central court are generally more elaborate than those in the divisional courts. One of the reasons for this marked difference is that almost all of the police special investigatory squads have their cases heard in the central court, and therefore much more police work has gone into the cases. Cases are usually presented by a police inspector who spends a considerable amount of time at the central court and who is familiar with magisterial practices.

18. Note, Metropolitan Criminal Courts of First Instance, 70 HARv. L. REv. 320, 325 (1956). The writer there notes that one attorney estimated that a reading of the charge was demanded in only one out of every 1,000 cases. 
merely narrate the details of the arrest, leaving their interpretation to the defendant. The magistrate and assistant district attorney have copies of the docket which list the precise offense. However, in no case observed did the magistrate inform an unrepresented defendant of the offense with which he was charged. If the accused is represented by an attorney, the magistrate or the assistant district attorney will generally permit the attorney to inspect the docket.

One reason for the failure of the preliminary hearing in Philadelphia to adequately fulfill its notice-giving function is the absence of any statutory elaboration as to what is required at the preliminary hearing. In contrast to this absence of any adequate statutory framework for the magistrates in Pennsylvania are the strict requirements provided by the Federal Rules of Criminal Procedure for the federal commissioners. ${ }^{19}$ The commissioner is required by the federal rules to inform the defendant of the complaint against him, of his right to retain counsel and of his right to remain silent. ${ }^{20}$ It is imperative that statutory guidance similar to these provisions be afforded the Philadelphia magistrates.

The preliminary hearing also permits the accused to face his accusers for the first time and so provides him an early opportunity to begin preparation of his defense. The testimony of witnesses taken at the preliminary hearing may in certain situations be admitted at the defendant's trial. ${ }^{21}$ Defense counsel agree that having all witnesses testify as fully as possible at the hearing affords some protection against surprise at the trial. Thus, in one case observed involving a gang charged with over twenty holdups, one defense counsel forced the member of the gang who was the state's principal witness to testify to every holdup in which his client was allegedly involved and the exact circumstances of each. Although the witness repeatedly stated he was having trouble remembering all the details of each holdup, the defense counsel persisted. Afterwards he stated to the court that he had proof that his client was in jail when at least three-fourths of the crimes charged to him had been committed. Excellent grounds on which to attack the credibility of the state's leading witness at the trial were thereby provided.

Frequently, however, the defense counsel is prohibited from making effective use of the preliminary hearing by magisterial rulings that a given line of questioning is irrelevant. There is some disagreement as to whether judicial rules of evidence apply to preliminary hearings. Carringer states that "the rules of evidence as to admissibility, relevancy and competency applicable to hearings before the magistrate, are the same rules enforced by the court of quarter sessions." 22 Generally, however, the magistrate is said by the authorities not to be governed strictly by the technical rules ap-

19. FED. R. CRIM. P. 5.

20. FED. R. CRIM. P. 5(b). (1935).

21. Orfifid, op. cit. stipra note 6, at 86;2 Wharton, Criminal Evidence 1111

22. Carringer, op. cit. supra note 5 , at 92 . 
plicable to a trial. ${ }^{23}$ Hearsay evidence may be considered, leading questions are permitted, and non-expert opinion is accepted. Apparently, however, most Philadelphia magistrates believe that their hearings are governed by the rules of evidence. Thus, although only two of the twenty-eight magistrates are attorneys, almost all attempt formal rulings. The assistant district attorneys and defense attorneys, who are presumably aware of the fact that strict evidentiary rules do not apply to preliminary hearings, encourage the practice by demanding that the magistrates formally rule on points of evidence. ${ }^{24}$ The results are far less satisfactory than other rulings predicated on the magistrates' common sense. There is a definite magisterial tendency to accept without question the assistant district attorney's contentions as to what the proper rules of evidence are. Too often magistrates sustain the prosecution's objection that a line of defense questioning is irrelevant. If one of the major functions of the preliminary hearing is to give the defense an opportunity to fully probe the state's case, defense questions should rarely, if ever, be declared irrelevant by a magistrate.

\section{Survey of Magisterial Practice in Finding Probable Cause}

The magistrate is entrusted with the duty of discharging those cases in which the state has not shown probable cause that a crime was committed and that the accused committed it. Meticulous sifting of cases at the beginning of prosecution is important both to the innocent and to the state. $^{25}$ Studies have shown that as many as fifty-eight per cent of all arrests are terminated at the preliminary hearing. ${ }^{26}$ Where the magistrate serves merely as a rubber stamp for the arresting authorities, both the state and the accused are put to unnecessary expense and inconvenience. ${ }^{27}$ The charge has sometimes been made that there has been such an abdication of independent judgment by magistrates in Philadelphia. ${ }^{28}$ On the other hand, it has also been charged that frequently magistrates "blow-out," i.e., illegally dispose of cases where probable cause has been shown. ${ }^{29}$ "Blow-outs" are said to occur primarily in "vice" cases. ${ }^{30}$ In this area suspicion of political activity is greatest and need for reform is most often cited. ${ }^{31}$

23. ORFIELD, op. cit. supra note 6 , at 88 and cases cited therein. This view seems the better one since no effective appeal from erroneous rulings is open to the wronged party.

24. All assistant district attorneys interviewed stated that they did not think the rules of evidence were strictly applicable to preliminary hearings but felt that they were useful in retaining at least a modicum of order in the hearing. But it was the writer's observation that attempts to apply the rules of evidence generally resulted in disorder.

25. "Manifestly the burden of the prosecutor is greatly increased if the examining magistrate commits indiscriminately, while enforcement of the law is relaxed if he discharges indiscriminately." National COMMITTEE OF LAW OBSERVANCE AND ENFORCE.MENT, REPORT ON PROSECUTION 21 (1931).

26. Moley, Politics and Criminal Prosecution 28 (1929).

27. Moley, Our Criminal Courts 33 (1930).

28. Interview with representative of the Committee of Seventy.

29. Interviews with assistant district attorneys.

30. Gambling, liquor and prostitution offenses.

31. E.g., Commuttee of Seventy, Civic Affatrs (1957). 
A rough estimate of the extent to which magistrates in Philadelphia are improperly discharging those arrested on vice charges or illegally committing in non-vice cases may be formed from an analysis of the testimony typically offered at the preliminary hearing and the results which follow. For this purpose a study was made through personal observation of hearings held from June 27 to August 20,1957 and by examination of the district attorney's pre-indictment files for 1956 and 1957. Of 1401 cases thus observed or examined 596 resulted in discharge of the defendant. These figures in themselves are inconclusive, however, since percentages of discharges vary greatly for different offenses. For this reason the writer selected seven common offenses for individual analysis. Three of the offenses analyzed, numbers, liquor, and prostitution, are so-called "vice" crimes; the other four, burglary, robbery, larceny, and narcotics are nonvice felonies.

\section{Lottery}

It is a crime in Pennsylvania to sell lottery or numbers tickets. ${ }^{32}$ However, the statute states that "the purchaser of such [lottery] ticket, policy or device shall not be liable to any prosecution or penalty. ..." 33 This distinction between selling and purchase of numbers tickets makes proof of the crime difficult. Of course, little trouble is encountered in showing probable cause where the suspect is arrested while actively receiving bets. ${ }^{34}$ In the common situation, however, the police arrest a man suspected of booking numbers and find in his possession slips of paper with number plays written on them. The burden is then on the state to demonstrate to the magistrate that the suspect was booking rather than playing these numbers. ${ }^{35}$

Apparently all magistrates regard this burden as difficult to meet unless among the numbers in the suspect's possession is at least one which is repeated several times. The reason given for demanding "repeats" is that a numbers player will not re-write a number when deciding which number to play whereas a numbers writer will probably have several of his players select the same number on a given day. This theory is so commonly accepted that some magistrates dismiss a case as a matter of course where there are no repeats.

Where the accused has an uncommonly large number of plays in his possession, but there are no repeats, disposition of the cases varies. In one case observed the police confiscated a notebook containing 182 notations of which about ten were repeats. The only peculiar element in the case was that the numbers contained four digits rather than the common three digits.

32. Pa. Stat. Ann. tit. 18, $\$ 4601$ (Purdon 1945).

33. PA. Stat. Ans. tit. 18, § 4602 (Purdon 1945).

34. Police Commissioner Gibbons stated recently that the new Pennsylvania statute banning wiretapping made arrest and conviction of numbers writers exceedingly difficult. Philadelphia Inquirer, Nov. 4,1957, p. 38 , col. 1.

35. See Commonwealth v. Saeli, 146 Pa. Super. 555, 22 A.2d 597 (1941). 
The accused contended that the notations represented a system of bookkeeping he used in operating his grocery store. The police, who had arrested the man before, were convinced that he was a bookmaker. During the course of the hearing the assistant district attorney remarked that he did not believe the accused's story, but felt that the man should be discharged. In discharging the accused, the magistrate remarked that anyone familiar with the mechanics of bookmaking knew that a numbers play involved only three digit numbers. No one mentioned the possibility of one digit being a dummy, e.g., the first or last three numbers being the only ones counted.

The case is extreme in view of the large number of plays and repeats in the confiscated notebooks. In other cases observed defendants were held where as few as thirty-one plays with repeats were confiscated. On the other hand, one alleged first offender was discharged though she had on her person some forty-nine plays with six repeats. Another defendant was discharged even though ten of the thirty-four notations in his possession were "boxed," i.e., the numbers were enclosed in a square allegedly denoting that the player would win if the three numbers he had picked came out in any one of the six possible combinations. ${ }^{36}$ The magistrate in discharging the case gave as his reason the fact that the numbers slips had been found in the defendant's bureau and that all members of the household had access to them. ${ }^{37}$ Of the forty-four hearings on lottery offenses personally observed twenty resulted in the defendant being held in bail for the grand jury. Of the three hundred fifty cases examined in the pre-indictment files of the district attorney, magistrates found probable cause for holding the accused in 162. Forty-four per cent of the suspects were held in cases personally observed; forty-seven per cent were held in cases tabulated from official files.

\section{Liquor}

It is unlawful " $[\mathrm{F}]$ or any person . . . to have or keep any liquor . . . within the Commonwealth unless the package ... in which the liquor is contained while containing that liquor bears the official seal of the liquor board." 38 More arrests occur for violation of this particular provision of the Liquor Code than for any other. The police generally classify the violation into two categories. The first is possession of recognized brand name liquors that have been smuggled into the state to be sold at a price lower than that charged by the state's retail stores. The second, possession of so-called "goathead" or "white whisky," produced in illegal stills, is re-

36. Cf. Commonwealth v. Banks, 98 Pa. Super. 432 (1930).

37. One assistant district attorney objected vehemently in another case discharged by the magistrate on this same theory. In that case there were bets noted beside the various number plays. Notation of amount is said to be indicative of writing because a player would have no trouble remembering how much he played whereas a bookmaker must write down how much each of his players has bet that day.

38. PA. Stat. Ans. tit. 47, §4-494 (4) (Purdon 1952). All unlawful acts relative to liquor, alcohol and liquor licensees are listed at PA. STAT. ANN. tit. 47, § $4-491$ (Purdon 1952). 
garded by the police, assistant district attorneys, and magistrates as a more serious offense. The magistrate has discretion to treat possession of untaxed liquor as a summary offense and to fine the defendant a maximum of twenty-five dollars. ${ }^{39}$ If the amount of liquor confiscated is relatively small and the accused has no previous record, magistrates generally exercise this discretion, although less commonly where the charge is possession of "goathead." 40

Proof of a prima facie case at the hearing is made easy by the nature of the offense. All that is required is testimony that the accused was found in possession of untaxed alcohol. In determining whether there is probable cause to hold the accused, the magistrate's function is, therefore, minimal.

Operation of a "speakeasy" is another common liquor offense. It is unlawful to keep for sale or to sell any liquor except in accordance with the provisions of the Liquor Code. ${ }^{41}$ Police procedure in these cases is to complete the sale before making an arrest. At the hearing the policeman's account of the events culminating in arrest is frequently contested by the suspect who protests that he had no intention of selling the drink to the officer but was merely being sociable in giving him a drink; any money that passed was given at the officer's insistence. Since in most cases the defendant has never seen the policeman before, such hospitality is somewhat suspect. ${ }^{42}$ A magistrate is probably correct in holding the accused in any case where money has passed since the possibility of entrapment by the officer is a matter for the jury. In "speakeasy" cases where the accused has refused to accept money from the policeman but confiscation of the accused's liquor supply has revealed possession of untaxed liquor, the magistrate holds the defendant for that offense rather than for an unlawful sale.

Figures compiled in the observation of liquor cases reveal that in the great majority the suspect is either held for the grand jury or the violation is treated as a summary offense. Of thirty cases observed, twenty-six resulted in such action. Of these twenty-six, the magistrates treated six as summary offenses. In all six the amount of liquor confiscated was small. Of 201 cases reported in the district attorney's pre-indictment file, 141 resulted in the defendant being held. The high percentage of defendants held do not substantiate the charges of improper discharges by the magistrates in liquor cases.

39. PA. Star. Ann. tit. 47, § 757 (Purdon 1952).

40. This of course is not always the case. At one hearing a magistrate, undecided as to whether he should fine or hold the defendants, called out to an unsworn police inspector "are we going to fine them?" The inspector replied "yes" and the magistrate then fined each of the three defendants twenty-five dollars and costs. It is interesting to note that the case was treated as a summary offense even though it involved "white whisky."

41. Pa. Stat. Ann. tit. 47, § 4-491(1) (Purdon 1952).

42. One particular defendant stated vehemently that he had often seen the policeman in the neighborhood. Although the policeman's account of the transaction did not obviate the possibility that the defendant did not intend to sell the liquor, the magistrate held the accused for the grand jury. 


\section{Prostitution}

Prostitution is the offering or using of the body for sexual intercourse for hire.43 It is unlawful to "commit prostitution or assignation" or "to permit any building to be used for prostitution ... . [or] to . . . take any person to any building with knowledge that the purpose of such . . . taking is prostitution." 44 Testimony in prostitution hearings is generally given by the arresting policeman who discussed the transaction with the accused and then at an appropriate moment placed her under arrest. The principal issue is whether or not the policeman offered the money in response to the defendant's demand. In one hearing observed, the officer testified that the only mention of money before arrest was the accused's question, "How generous are you going to be?" The magistrate, stating that he felt this question ambiguous, ${ }^{45}$ dismissed the case over the objection of the assistant district attorney.

Arrests are also made where the police notice a woman known to them to be a prostitute entering a house with a man. The showing of probable cause in these cases is more difficult in that the patron, though he admits to the police that he was to pay the accused, will frequently deny this at the hearing the following morning. ${ }^{46}$ The magistrates seem inclined to dismiss the charges in such an eventuality and in none of the cases observed was any objection made by the assistant district attorney. Aside from these cases the percentage of defendants held in prostitution hearings is relatively high. This is probably attributable to the positive character of the police testimony which allows the magistrate little discretion. However, it was the writer's personal observation that many cases were dismissed under rather questionable circumstances. Of twenty-one cases observed, the accused was held in twelve. Of fifty-four cases reported in the district attorney's pre-indictment file, forty resulted in the defendant being held. A number of the dismissals reflect the solicitous attitude adopted by some magistrates when dealing with women accused of prostitution. Especially where a first offender is involved, the inconvenience and embarrassment of the arrest and preliminary hearing may be deemed by the magistrate to be sufficient punishment. Some dismissals may result from the fact that the accused in a prostitution case is more often represented by counsel than are suspects in other misdemeanor hearings.

\section{Narcotics}

It is a crime in Pennsylvania for any person to use, possess, or sell certain specified drugs in any manner not expressly authorized by statutes. ${ }^{47}$

43. Pa. Stat. Ann. tit. 18, § 4103 (Purdon 1945).

44. Pa. Star. ANn. tit. 18, § 4512 (Purdon 1945).

45. Presumably the ambiguity, if there was any, should have been settled by the jury since there was at least probable cause to hold the defendant.

46. One assistant district attorney noted that the patron is also guilty of prostitution but stated that he is rarely held unless the prosecution wishes to assure his presence before the grand jury.

47. Pa. Srat. Ann. tit. 35, § 821 (Purdon Supp. 1957). 
More severe penalties for second and third offenders are prescribed. ${ }^{48}$ Since criminal intent or guilty knowledge are not elements of the offense, the magistrate's task in determining whether or not probable cause exists is a relatively simple one. ${ }^{49}$ All that must be determined is whether the defendant had in his possession a substance found to be a drug or whether the defendant, when examined, was under the influence of prohibited drugs. The police book only those suspects who have in their possession suspicious substances or who have marks of hypodermic injections on their arms. ${ }^{50}$ In possession cases, the police procedure is to have the substance analyzed immediately. At the hearing, either the analyzing chemist testifies as to the result of his analysis or, more commonly, the arresting officer reads the laboratory report. If the test reveals the substance to be a prohibited drug, the accused is held. Similarly, in use cases the defendant himself is subjected to a test. If he is pronounced positive by the doctor, he is held by the magistrate as a matter of course.

The following case was declared to be a typical one by the arresting officer. The defendant, who had been arrested ten times previously for drug offenses, was found upon examination by the officer to have marks on his arm. An eyedropper and a spoon were found on his person. Upon analysis the spoon was found to contain a residue of heroin. A doctor testified that his examination revealed that the defendant had recently taken a narcotic drug. At the hearing the defendant refused to answer any questions. His attorney, obviously reconciled to the fact that his client was to be held for the grand jury, confined his remarks to a plea for reasonable bail.

Of some forty cases personally observed, only fifteen defendants were held. Of the twenty-five discharged, all had been arrested for use and had been pronounced negative upon medical examination. Of seventy-six cases tabulated from official files, thirty-four resulted in the defendant being held for the grand jury. In every possession case, analysis of the confiscated material revealed it to be a prohibited drug. In the opinion of the writer these statistics cast little light on the operation of the preliminary hearing since the magistrate has so minimal a function. If the defendant has been pronounced negative upon examination, both the assistant district attorney and the police officer recommend discharge. Discharge follows as a matter of course.

\section{Burglary}

The felony of burglary is committed when a building ${ }^{51}$ or vehicle ${ }^{52}$ is entered with intent to commit a felony. If a man breaks into a house or

48. Pa. Stat. Ann. tit. 35, § 865 (Purdon Supp. 1957).

49. Commonwealth v. Gorodetsky, $178 \mathrm{~Pa}$. Super. 467, 115 A.2d 760 (1955).

50. Note, Philadelphia Police Practice and the Law of Arrest, 100 U. PA. L. REp. 1182,1194 (1952).

51. PA. Star. ANn. tit. 18, § 4901 (Purdon 1945).

52. PA. Stat. Ann. tit. 18, § 4903 (Purdon 1945). 
building, the felonious intent may be inferred from the breaking. ${ }^{53}$ Absent an actual breaking, some other reasonable basis must be found upon which to found the inference of intent. ${ }^{54}$ Of twenty-seven cases observed, all resulted in the accused being held without bail. Of ninety-two cases reported in the district attorney's pre-indictment file, the suspect was held in eightysix cases. The magistrate has power to reduce the charge of burglary to a lesser offense if he is not satisfied that the state has shown probable cause to believe that the defendant had the requisite felonious intent. ${ }^{55}$ In other cities it is reported that the district attorney and defense counsel frequently agree to reduce the offense to one over which the criminal court of first instance has jurisdiction. ${ }^{58}$ However, in no case observed in Philadelphia did the magistrate exercise his power to reduce a charge of burglary even though the showing of probable felonious intent in many cases was weak. ${ }^{57}$ Since the magistrate is without power to set bail in burglary cases, ${ }^{58}$ the consequences for a defendant held by a magistrate on a charge of burglary rather than a lesser crime are important..$^{59}$

\section{Larceny}

Larceny is the felonious taking and carrying away of the personalty of another, and the fraudulent taking and carrying away of a thing without a claim of right, with the intention of converting it to a use other than that of the owner without his consent. ${ }^{60}$ The magistrate has discretion to settle larcenies involving less than $\$ 200 .{ }^{61}$ Approximately half of the larceny hearings observed involved shoplifting. Recently a statute was enacted giving the magistrate the option to treat shoplifting as a summary offense, rather than as the felony of larceny. ${ }^{62}$ The district attorney's memorandum to magistrates on this new statute stated that the magistrate in the exercise of his option should consider the circumstances of the taking, the value of the articles taken, and the prior criminal record of the defendant. ${ }^{63}$ Thus,

53. Commonwealth v. Hartland, 147 Pa. Super. 263, 24 A.2d 160 (1942). MILLER, Criminal LaW 338 (1934).

54. Commonwealth v. Ellis, 349 Pa. 402, 37 A.2d 504 (1944).

55. If no probable cause of burglary has been shown because of lack of felonious intent, probably a larceny has been shown.

56. Cf. Ploscowe, The Inferior Criminal Courts, 25 N.Y.U.L.Q. REv. 42,47 (1950).

57. One particularly striking case involved a defendant charged with stealing a pocketbook while prowling in a children's hospital. The pocketbook was found in a yard near the hospital and an identification of the accused as the man seen prowling was made. This evidence was undoubtedly sufficient to make out a prima facie case of larceny. There was no evidence offered, however, of a breaking or entering on the part of the defendant nor of a felonious intent at the time of entering, yet he was held without bail on the charge of burglary.

58. PA. Stat. ANN. tit. 19, \$ 51 (Purdon 1930).

59. The requirement that the judge of common pleas set bail rather than the magistrate frequently operates to deprive a defendant of bail. Foote, Compelling Appearance in Court: Adininistration of Bail in Philadelphia, 102 U. PA. L. REv. 1031, 1044 (1954).

60. Commonwealth v. Quinn, 144 Pa. Super. 400, 19 A.2d 526 (1941); PA. STAr. ANN. tit. 18, \$ 4807 (Purdon 1945) provides the penalty without defining the crime.

61. PA. Star. ANN. tit. 19, \& 491 (Purdon Supp. 1956).

62. PA. Legrslative SeRv. 597 (Purdon 1957).

63. Interview with an assistant district attomey. 
in consecutive cases, one assistant district attorney recommended that a defendant who had taken a $\$ 29.95$ dress but had no record be fined and that another defendant who had taken ten $\$ 1.00$ shirts but had a record of six arrests be held for the grand jury.

The percentage of dismissals is much higher for larceny cases than for other felonies. The major reasons are the power of the magistrate to settle larcenies and the frequent failure of prosecuting witness to appear. Of twenty-one cases observed, fifteen resulted in the defendant being held. The accused was held in 112 of 158 cases reported in the district attorney's pre-indictment file.

\section{Robbery}

Robbery consists of forcibly and feloniously taking from the person or presence of another money or goods of any value by means of violence or the putting of that other person in fear. ${ }^{64}$ Since the forcible taking from the victim is an essential element of the crime, the victim is generally the chief witness and an identification by him is the most important element of the Commonwealth's showing of probable cause. The police will generally request a continuance if the victim is unable to attend the hearing.

A: substantial number of robbery arrests are made on the basis of the victim's description of the robber. ${ }^{65}$ The accused is then confronted with the victim or the victim attempts to pick the robber from a lineup. There is the possibility that the accuser, though unsure on confronting the suspect, may be coaxed into an identification by the police. Thus, there is a positive advantage in the preliminary hearing in that the witness must there identify the accused under oath. In a number of cases observed, defense counsel were able to extract from witnesses admissions of uncertainty. One victim, when confronted with the alleged robber, a negro, said he was not sure of his identification since "they all look alike." A suspect is often held for robbery on the basis of an alleged accomplice's statements. In one case the victim could only identify two of three defendants. However, the two defendants who had been identified implicated the third and he too was held for court.

In robbery cases as in burglary and larceny cases, the percentage of defendants held for the grand jury is high. Of twenty cases observed, suspects were held for the grand jury in eighteen; fifty-seven out of sixtythree cases reported in the district attorney's pre-indictment file resulted in the defendant being held. In every case observed in which the accused was held, either the victim was present and identified the suspect or the suspect confessed. ${ }^{68}$ Confronted with this kind of showing of probable cause, the magistrate should seldom find occasion to dismiss.

64. Commonwealth v. Darcy, 362 Pa. 259, 66 A.2d 663, cert. denied, 338 U.S. 862 (1949).

65. Note, Philadelphia Police Practice and the Law of Arrest, 100 U. PA. L. Rev. 1182,1190 (1952).

66. The magistrate can not hold the defendant on a confession alone. There must be a corpus, i.e., the fact that the alleged crime was committed must be established. In 


\section{Summary}

Of the offenses considered, only in lottery and perhaps in prostitution cases do there appear to be frequent improper dismissals. Conversely, only in burglary cases did observation indicate that suspects are often held without an adequate showing of probable cause. Illegal political influence may be responsible for some "blow-outs." Others are apparently the result of an apathetic or even sympathetic attitude on the part of magistrates toward certain species of vice offenses. There are several possible explanations for unjustified committals. First, the accused at a preliminary hearing is seldom represented by counsel with the result that the hearing often becomes a perfunctory recitation of the facts by the arresting officer. Another is that few Philadelphia magistrates are lawyers. ${ }^{67}$ In an offense such as burglary which involves an element of intent, legal questions may arise which the layman is not trained to resolve. As a result the magistrate may tend to accept the suggestions of the assistant district attorney, the only attorney present. A third factor is that newspaper and police pressure for curtailment of crime may induce magistrates, elected officials, to hold defendants unjustifiably, rather than risk public accusation that they are freeing criminals. Finally, the burden upon the police to produce evidence showing probable cause within not more than twenty-five hours after arrest may be so unrealistic as to lead a magistrate to refuse to discharge an accused for insufficient evidence when he believes that in all probability subsequent investigation will confirm the accused's guilt.

\section{Role of the District Attorney in the Determination of Probable Cause}

Failure of magistrates to exercise any real judicial function in certain cases and the infrequent presence of defense counsel have thrust additional obligations upon the assistant district attorney present at the hearing. ${ }^{68}$ Where no prima facie case has been made out, it is his duty to recommend that the magistrate discharge the defendant just as he may recommend holding the suspect when probable cause has been shown. Assistant district attorneys recognize that they are under a greater obligation to protect the defendant's rights at the hearing than the prosecution assumes at later

some cases, this presents a minor practical problem. For example, if the victim does not appear and none of the policemen present has spoken to him directly, the magistrate should theoretically dismiss the case. Often, however, under these circumstances, the defendant will be held for the grand jury. If defendant's counsel objects on the grounds that no corpus delicti has been proved, the assistant district attorney will request the magistrate to continue the case until such time as the victim is located. See CARRINGER, Procendure Before Commitiming Magistrates in Pennsylvania 87 (1947); Note, Proof of the Corpus Delicti Aliunde the Defendant's Confession, 103 U. PA. L . REV. 638 (1955).

67. Only two of twenty-eight magistrates are lawyers.

68. The Magistrates Court Act of 1937 provides that "the district attorney of the county of Philadelphia may assign such number of his assistants as may be necessary to be present at and conduct on behalf of the Commonwealth all criminal hearings held in the central police court and divisional police courts. ..." PA. STAT. ANN. tit. 42, § 1142 (Purdon Supp. 1956). Under present procedure, an assistant district attorney is generally assigned to a divisional court for about a week. 
stages of trial. However, as prosecutors, they may, of course, be unable to achieve fully the objectivity that judicial decision requires. ${ }^{69}$

In addition to recommending action at hearings, the district attorney has other means at his disposal to influence the disposition of cases at the pre-grand jury stage. The district attorney has discretion to request nol pros for cases in which he feels prosecution is unwarranted. ${ }^{70}$ Conversely, under present procedure he has the power to order rearrest if he feels that the case has been improperly dismissed. These powers may, of course, be exercised in such a manner as to indicate to the magistrate disagreement with his handling of the case.

\section{Rearrest}

The magistrate's finding that there is no probable cause is not necessarily final. ${ }^{71}$ If the magistrate dismisses a case, the police are not precluded by rules of former jeopardy from rearresting the defendant for the same offense and bringing him before a different magistrate or even the same magistrate. ${ }^{72}$ In Philadelphia, if the police or assistant district attorney feel that a magistrate has improperly dismissed a case, their procedure is to obtain a warrant for the rearrest of the accused and then to bring him before a judge of the court of quarter sessions who has agreed to sit as a committing magistrate. ${ }^{73}$ Through judicious use of rearrest, not only are improper dismissals prevented, but in addition, documentation is provided for charges that a given magistrate is dismissing too many cases in which probable cause has been shown.

Before a rearrest is made, the present administration demands that a complex procedure be followed. ${ }^{74}$ The requests for rearrest may originate with the arresting policeman or the assistant district attorney who was present at the hearing. In the case of a police request, higher police authorities first screen the officer's report. If they feel that a rearrest is in order, they then forward the request to the district attorney's office where it is reviewed by the first and second assistant district attorneys who have before them also the report of the assistant district attorney who was present at the preliminary hearing. The final decision is made by the district attorney himself from all these reports. ${ }^{75}$

One assistant district attorney stated that where this rearrest procedure was strictly followed, almost every rearrest resulted in the defendant being

69. All assistant district attorneys interviewed stated that they felt such an obligation existed.

70. PA. Stat. ANN. tit. 19, § 492 (Purdon 1930). For an excellent discussion of the use of nolle prosequi, see ORFIEID, op. cit. supra note 6 , at 337 .

71. A preliminary examination of one arrested on suspicion of a crime is not a trial; a discharge of the accused is not an acquittal. Collins v. Loisel, 262 U.S. 426 (1923); ORFIELD, op. cit. supra note 6 , at 93.

72. Ervin, The Magrstrates' Courts of Phinadeiphia 23 (1931).

73. Interview with assistant district attorney. See PhILADELPHIA DisTrICr ATTORNEY'S OFFICE, ANNUAL REPORM 10 (1953).

74. Interview with Mr. Jerome Balka, Chief of Indictment Division, District Attorney's Office, Philadelphia County.

75. Recently this procedure was changed temporarily because transcripts of the hearings have been unavailable. Under present procedure the district attorney and his first and second assistants interview the complaining officer. 
held by the court of quarter sessions. He noted, however, the great pressure on the district attorney to rearrest, even in questionable cases. High ranking police officials have publicly attacked the district attorney's rearrest procedures on numerous occasions, though the police often request rearrest on the basis of the defendant's record without a careful screening of the facts in the individual case. ${ }^{76}$ The district attorney was said to be put in the unenviable position of either refusing to prosecute so-called known criminals or authorizing rearrests in cases where he felt this to be unwarranted. The assistant district attorney blamed the increased number of cases dismissed by quarter sessions judges on this situation. ${ }^{77}$

Recently the police commissioner unilaterally obtained warrants for the rearrest of forty-seven individuals who had been arrested in city-wide vice raids, the district attorney having refused to give his approval. Thirty of these cases, which were heard by a judge of the common pleas, were dismissed for lack of probable cause. Protection of the accused against illegal arrest makes it particularly important that such unilateral requests by the police be critically scrutinized for probable cause by the magistrate asked to issue the warrants. There has already been a determination by a judicial officer that no probable cause exists for holding the defendant and the prosecuting authorities have indicated a willingness to accept this determination.

Frequent conflicts between police and prosecuting authorities over rearrest procedure are the most graphic illustrations of the importance both attach to rearrest as a means of supervising magistrates' actions. The district attorney has had great success with rearrest both as a corrective measure for individual decisions and as an implied warning to certain magistrates to discontinue illegal practices.

\section{Nolle Prosequi}

Analysis of nolle prosequi figures should presumably indicate those fields in which the prosecutor believes that magistrates tend to improperly hold accused persons. One report from the district attorney's office stated that four offenses give rise to almost ninety per cent of the cases submitted for nol pros or ignored by the grand jury. ${ }^{78}$ They are simple assault and battery, larceny, obtaining goods by false pretenses and common gambling. ${ }^{79}$ Simple assault and battery is the type of case most frequently nol prossed prior to presentment to a grand jury despite the fact that over

76. Police are often disheartened by the discharge of a man they "know" to be a criminal. They frequently request rearrests merely on the belief that the "criminal" should be indicted, even though the facts of arrest do not justify holding the man.

77. The latest figures available on rearrests showed that of 380 requests for rearrests from all sources, 154 requests were refused; eighty-nine requests were approved and were pending further action; ninety-six were approved and had resulted in the accused being held by the committing magistrate; forty-one were approved and had resulted in discharge by the magistrate. It was also pointed out that the district attorney's office is especially susceptible to pressure for unwarranted rearrest in an election year.

78. Pailadezphia District Attorney's Office, Memorandun to Magistrates ON Proper Procedure (1957).

79. Id. at 3 . 
forty per cent of those arrested on this charge are dismissed at the preliminary hearing. ${ }^{80}$ The major reason for nol prossing assault and battery cases is failure of prosecution. The prosecuting witness, often a friend or relative of the accused, may have been intent on prosecution at the hearing on the morning following the assault. But by the time that the bill is ready for the grand jury, his temper may have cooled substantially. It cannot be said that the magistrate's action in holding the suspect for the grand jury was improper in these cases, but the district attorney has suggested that the magistrates take a more positive role in informing the victim of his civil remedies in the hope that he will withdraw his criminal charges at the hearing rather than later. ${ }^{81}$ Such withdrawal is of course subject to approval by the Commonwealth but would probably be approved as a matter of course in cases not involving serious injury.

Larceny of small amounts is another area that is particularly prone to later nol pros by the district attorney. The magistrate has the power to settle larcenies where the amount involved is less than two hundred dollars. ${ }^{82}$ If the prosecutor is satisfied to receive restitution and the defendant has no criminal record ${ }^{83}$ the district attorney's office suggests that the magistrate allow the compromise to take place and to discharge the defendant. ${ }^{84}$ As in the simple assault and battery cases, the principal reason for the frequency of nol pros is the reluctance of the prosecuting witness to testify once restitution has been made. Wise exercise of the magistrate's discretion in this area can be beneficial in halting prosecutions where all parties involved are satisfied that the defendant has been sufficiently reprimanded. ${ }^{85}$

The crimes of common gambling ${ }^{86}$ and obtaining goods under false pretenses ${ }^{87}$ give rise to a disproportionate number of nol pros actions because of magisterial misunderstanding of the elements of the crimes. An element of the crime of common gambling is that the defendant is without a place of residence. ${ }^{88}$ The arresting officer is frequently unable to testify on this point but the defendant is nevertheless held, only to be released later. If the district attorney is present, he should advise the magistrate when evidence has not been introduced regarding an essential element of the offense.

80. Percentage determined from observation during summer of 1957.

81. The magistrate may discharge a prosecution for assault and battery if it is not "well-founded." PA. STAT. ANN. tit. 19, \& 21 (Purdon 1930); Id. tit. 19, § 22 (Purdon Supp. 1956). CARRINGER, op. cit. supra note 66, at 98.

82. Pa. Stat. AnN. tit. 19, \& 491 (Purdon Supp. 1956).

83. One magistrate mentioned a case in which a youthful defendant with no criminal record was charged with larceny of a television set from his employer's warehouse. The employer had a very high regard for the boy yet felt it his duty to report the theft. Restitution had been made immediately. The one complication was that the television set was said to be worth about three hundred dollars. To the surprise of no one and with no objection, the magistrate declared that it sounded to him as if the set mentioned were worth two hundred dollars and then proceeded to settle the case within the authority granted him.

84. Interview with an assistant district attorney.

85. Philadelphia DisTriCT AtTORNEY's OFFICE, op. cit. supra note 78.

86. PA. STAT. AnN. tit. 18, \& 4603 (Purdon 1945).

87. Pa. Star. AnN. tit. 18, \& 4836 (Purdon 1945).

88. Pa. Stat. AnN. tit. 18, $\$ 4603$ (Purdon 1945). 
The district attorney apparently does not consider that his discretionary power to request nol pros empowers him to review those cases in which defendants have been held without probable cause. Nol pros does protect the defendant held where an element essential to a prima facie case has been omitted. Prosecution is most frequently withdrawn, however, because of the unavailability of witnesses. ${ }^{80}$ Presumably, the presence of an assistant district attorney at the preliminary hearing prevents egregious error; the grand jury is the proper forum for the discharge of cases in which probable cause has not been shown. By the nature of his office the district attorney is not qualified nor should he be permitted to review in a judicial manner the determinations of the magistrates. ${ }^{90}$

\section{Continuances}

The Pennsylvania Supreme Court has said, "In the conduct of . . . [preliminary] hearings, the magistrates have the power to adjourn and to demand security for appearances at a future date in order that they may fully investigate the matter before them." 01 Very rarely in practice does the magistrate adjourn or continue a case on his own motion. Generally the continuance is granted upon police request. Indiscriminate granting of these requests could foster police reliance on post-arrest investigation, a police practice supposedly halted by the combination of prompt arraignment with a preliminary determination of probable cause for holding the defendant.

The most frequent prosecution reason for continuance is the absence of a vital witness. ${ }^{92}$ Occasionally the police request a continuance for an individual defendant "to complete investigation," without introducing evidence sufficient to justify holding the defendant.93 More frequently, such continuances without showing of probable cause are requested for members of gangs, arrested individually, so as to consolidate their hearings. Many magistrates grant such requests without question. The potential for abuse of the defendant's rights by such procedures is manifest. Even if the police have probable cause for holding the accused, they have not shown such cause at the preliminary hearing. The defendant is required without a showing of the reasons for his detention to put up bail, or, if the offense is not bailable by the magistrate, to undergo commitment until such time as he has bail set by a judge of quarter sessions.

89. Philadelphia District Atrorney's OfFrce, op. cit. supra note 78, at 5.

90. Orfield, op. cit. supra note 6 , at 337 .

91. McNair's Petition, 324 Pa. 48, 54, 187 At1. 498, 501 (1936).

92. Interview with an assistant district attorney. Absence of witnesses is particularly prevalent in assault and battery cases where the injured party is in the hospital and long postponements are necessary.

93. One source stated that it was a common police practice to arrest a man and ask the magistrate for a continuance for "investigation." The police then put him in a lineup. If he is not identified at the lineup, the police then state to the magistrate that their investigation revealed that the defendant was innocent, and should be discharged. The existence of such a practice seems unlikely. Obviously police, magistrates or assistant district attorneys would not admit to such a practice if one existed. However, most defense counsels stated that they knew of no such practice and the writer encountered no cases that seemed to substantiate the charge. 
Justification for continuances without any showing of probable cause has been sought in the need of the police to arrest a suspect before he flees from the jurisdiction. ${ }^{94}$ This argument ignores present law which emphasizes the right of the individual against arrest on mere suspicion. ${ }^{95}$ However, the existence of such a police practice is significant in itself. If magisterial granting of continuances emanates from a realization that police need demands such a practice, perhaps a reevaluation of the present law is in order. Conceivably the safest way to provide some flexibility for the police is to grant continuances where the circumstances of arrest make an immediate showing of probable cause impossible ${ }^{96}$ or impractical. ${ }^{97}$ The accused has been brought before a judicial officer promptly thereby minimizing the danger of police third degree. ${ }^{98} \mathrm{He}$ will either be released on bail or detained by prison rather than police authorities if bail is not forthcoming, and he will have had an opportunity to contact his family and attorney.

\section{ConClusions}

As presently conducted in Philadelphia, the preliminary hearing protects the defendant against only egregious police error. ${ }^{99}$ The principle objection to a more probing preliminary hearing is that anything more than a superficial showing of probable cause places an unrealistic burden upon police already forced to produce proof of guilt in a matter of hours. In fact, the present liberal granting of continuances and frequently uncritical determination of probable cause may be due in part to magisterial realization that the stringent requirement of prompt arraignment requires some leniency at the preliminary hearing. However, it is submitted that the greater protection afforded the accused by strict adherence to the probable cause rule outweighs the increased burden upon the police. Moreover, if extension of police power is desired, it would seem that such extension should be made by broadening the permissible limits of pre-arrest procedure, e.g., lawful detention and interrogation by the police for short periods of time, ${ }^{100}$ rather than subjecting illegally detained defendants to the expense and embarrassment of continued detention. Two of the major reasons for the present limited effectiveness of the preliminary hearing are capable of correction. First, the lack of defense counsel might be corrected by (1) a requirement that the defendant be notified of his right to a con-

94. Interview with member of police investigatory squad.

95. Note, Philadelphia Police Practice and the Law of Arrest, 100 U. PA. L. REv. 1182, 1184 (1952).

96. The amendment of the present laws of arrest as suggested by the Uniform Code of Arrest would make more probable a situation where the initial arrest is legal but the police are incapable of proving probable cause. UNIFORM LAW OF ARREST \$ 6(2) (B), 28 VA. L. REV. 315, 345 (1942).

97. One police officer stated that the reason for the police request for continuance is to prevent the members of the gang who are still free from learning of the arrest of one of their cohorts and fleeing.

98. See text and note at note 4 supra.

99. See pp. 590-93 supra.

100. UNIFORM LAw OF ARREST \& 2(3), 28 VA. L. REv. 315, 344 (1942). 
tinuance of the hearing so that he may obtain counsel; ${ }^{101}(2)$ enlargement of the facilities of the voluntary defender so as to permit him to be present at preliminary hearings. ${ }^{102}$ Second, the failure of the magistrates to properly exercise their judicial function might be corrected by (1) requirement that all magistrates be lawyers; (2) making the office appointive rather than elective; (3) lengthening the magistrate's term of office; (4) requiring that all preliminary hearings be held in the judicial atmosphere of the City Hall rather than at the rather dingy stationhouses where most are presently held. ${ }^{103}$

In general, more explicit statutory requirements for the preliminary hearing are necessary. Statutory provision should be made for prompt presentment and for informing the defendant of the charge against him and of his right to make a statement. The magistrates should also be provided with a statutory elaboration of their power to grant continuances. The statute drafted for the Code of Criminal Procedure by the American Law Institute is consistent with the scrupulous protection against unjustified detention deemed essential by this writer:

"The magistrate may for good cause postpone the examination. If no postponement is had, the examination shall be completed at one session. No postponement shall be for more than two days, nor shall the postponements in all exceed six days, except for good cause." ${ }^{104}$

It is believed that the only prosecution reason sufficient to satisfy the requirement of good cause is the failure of a witness to appear. Even in these cases there should be an obligation on the police to recount the nature of the testimony that would have been offered and to show that with such testimony there is probable cause for holding the defendant. Continuances to complete investigation would definitely be prohibited by this statute. Similarly, requests for continuances to permit the prosecutor to consolidate the hearings of the members of a gang who are arrested individually should not be granted.

R. $R$.

101. Defendants presently are not informed of this right.

102. A representative of the Voluntary Defender stated they are presently unable to attend preliminary hearings for financial reasons. Also the Voluntary Defender cannot defend anyone who is financially able to hire an attorney. One writer has suggested the use of public prosecutors at the preliminary hearing. Note, Metropolitan Criminal Courts of First Instance, 70 HARv. L. REv. 320, 345 (1956).

103. See PA. Stat. ANN. tit. 42, $\S 1110,1111$ (Purdon Supp. 1957).

104. ALI, Code of Criminal Proceddure $\$ 43$ (1930). 